\title{
Controversial NIH genome researcher leaves for new \$70-million institute
}

Washington. The US National Institutes of Health (NIH) researcher whose patent applications for thousands of partial gene sequences have inflamed the genome community is leaving NIH to start what is expected to be the world's largest gene sequencing laboratory. J. Craig Venter announced this week that he will resign from NIH on 10 July to head a new \$70-million nonprofit research centre called the Institute for Genomic Research (IGR). By the time the privately funded institute gets up to speed, it is expected to include some 70 scientists and to be identifying some 2,000 gene markers a week.

Venter says the new institute aims to "do the genome project", starting from industrial-scale cDNA sequencing and moving to gene mapping and biology as well. With a core operation based around 18-20 robotic gene sequencers from Applied Biosystems Inc., Venter estimates that the institute will eventually be able to sequence as many as 60 million bases - one-fiftieth of the entire human genome - a year.

The IGR's initial funding comes from a ten-year grant from the Healthcare Investment Corporation, a venture capital group based in Edison, New Jersey, and backed by several corporate pension accounts. It has started other NIH-related biotechnology companies, including Genetic Therapy Inc. In addition to the IGR, the venture fund is creating a new biotechnology company, Human Genome Science Inc., to develop and market products based on IGR technology and discoveries. Both the new company and the IGR will be located in Montgomery County, Maryland, near NIH.

Venter says the IGR will initially concentrate on a ten-fold scale-up of his efforts to sequence random fragments of cDNA, known as Expressed Sequence Tags (ESTs). Researchers hope that a database of ESTs, which are markers for expressed genes, will help them to link genes with known function in model species (such as yeast and the mouse) to genes that may have similar function in humans. There are an estimated 50,000100,000 human genes, for which fewer than 10,000 ESTs have been sequenced.

IGR researchers will also work on full sequencing of DNA clones, with an eventual target of sequencing an entire chromosome. Other projects will include sequencing full cDNAs (rather than just fragments), and the sequencing of the genomes of model species such as yeast, Caenorhabditis elegans and Drosophila, Venter says. A parallel effort will focus on genome biology, including research on gene expression and receptors.

Venter intends to take his NIH team with him, and will soon be joined by his wife, Claire Fraser, a molecular receptor biology researcher, and her team at the National Institute on Alcohol Abuse and Alcoholism. Other recruits are expected to include specialists in gene sequencing technology and negotiating with IBM for an additional grant, on the order of several tens of million dollars, to fund cooperative development of genome-related computer technology.

The new institute appears to accomplish much of what Frederick Bourke, a wealthy US entrepreneur, had hoped to create last year (see Nature 355, 483; 1992). After Bourke's international recruiting effort failed to entice several key researchers, his project lost momentum and now appears to be in abeyance. Unlike Bourke's proposed company, IGR is not intended to be supported by government grants or outside contracts; it may, in fact, send money the other way, in the form of cooperative agreements to support research at NIH.

Given the controversy about Venter's gene patents at NIH, the intellectual property policy of the new institute is expected to dent of the Healthcare Investment Corporation, says that the founders have not yet settled on a patent policy, "but we will be studying the problem very carefully". Other companies started by the venture capital fund have adopted the standard industry a "major gene mapper", Venter says. He is be watched closely. Wallace Steinberg, presi-

policy of patenting genes only when they are fully sequenced and their function is known, and the new company is expected to start out with that position. Its final decision will depend on both the policy of the NIH and any decisions on the issue by the US patent office, Steinberg says.

News of the new institute was welcomed by several researchers this week as both an acknowledgement that the genome project is ready for scale-up and that industry recognizes its long-term commercial potential. "I think that everyone agrees that they don't want to let [large-scale] sequencing choke the academic community," says Richard Gibbs, a sequencing research at the Baylor College of Medicine. "I think the community is going to very pleased" to see industry fund the labour and technology intensive sequencing effort, leaving much of the mapping and gene biology to smaller university research teams, he says. "I can't see how this is anything but a shot in the arm for the whole [genome] project."

Victor McKusick, the Johns Hopkins University researcher who pioneered the genome project, predicts that there will be an "initial sense of unease" at the prospect of the world's largest gene sequencing operation being run by as controversial a figure as Venter. But as a whole, "the trajectory [of the initiative] is in the right direction. This is what it's going to take to get the job done."

Christopher Anderson

\section{Solar observatory shaken by quake}

Washington. Among the casualties of last week's double earthquake in the sparsely populated Mojave desert of California were telescopes at the Big Bear Solar Observatory, about 80 miles northeast of Los Angeles. The epicentre of the second earthquake, which measured 6.5 on the Richter scale, was a mere five miles from the observatory, which is on a small island in Big Bear Lake. Damage to the observatory itself was amplified because its foundation rests on soft lake-bottom soil; the main office on the shore was damaged only to the extent of a few cracked walls.

The concrete pedestal and mounting of the largest telescope, a 26-inch reflector, was destroyed and will have to be rebuilt. The two other main instruments, an eightinch and ten-inch refractor, were also put out of action because of damage to their mountings. The good news, according to Bill Marquette, chief observer at Big Bear, is that the optical equipment of all three telescopes appears to have escaped damage.

Marquette estimates that it will take a month or two, and about $\$ 300,000$, to rebuild the mountings, which had been damaged and then strengthened after a 4.9nia Institute of Technology, which owns and operates the observatory, has promised to help pay for the reconstruction, and additional support may come from one or more of the federal agencies that support research there.

The period of inaction will mean a considerable loss of data. Big Bear normally produces two or three thousand solar observations every day, and about 3,000 feet of $35-\mathrm{mm}$ film a week, and distributes it worldwide. No other solar observatory produces such a quantity or range of fundamental solar data.

David Lindley magnitude earthquake in 1979. The Califor- 